\title{
Comparative Story Drift Analysis of High Rise Building Structure between X-Braced Frame and Two Story X-Braced Frame
}

\author{
Sayed Ahmad Fauzan ${ }^{1}$, Nugraha Bintang Wirawan ${ }^{1}$, Ahmad Yudi ${ }^{1}$ \\ ${ }^{1}$ Civil Engineering Department, Institut Teknologi Sumatera, South Lampung, Lampung Province, Indonesia.
}

\begin{abstract}
The high-rise building of steel structures requires strengthening system so that buildings are capable of carrying earthquake loads that may occur. Strengthening of steel structure building can be applied by providing stiffness of the structure in the form of mounting lateral stiffening system using eccentrically braced frame or concetrically braced frame. The purpose of this study is to analyze performance of story drift of the building structure in the form of horizontal drift values due to earthquake load on the building structure using the stiffening lateral x-braced frame and the two story x-braced frame. The research method using load of dynamic earthquake response spectrum analysis in accordance to SNI 03-1726-2012. The building models have 12 floors, located in Lampung city and was planned behave as an Intermediate Moment Resisting Steel Frame (IMRSF). Building model was designed and anlyzed using ETABS Version 9.7. This study shows story drift in type two story x-braced frame is smaller than the $\mathrm{x}$-braced frame.
\end{abstract}

\section{Introduction}

Some of regions in Indonesia was transversed by ring of fire. It caused by Indonesia regions was located between eurasian plate, philipina plate, pacific plate and Indo-Australian Plate. The big event of seismic earthquake and tsunami in Indonesia, namely: on $26^{\text {th }}$ December 2004 earthquake and tsunami occured in Aceh district, Sumatera island with 9.1 Magnitude and then on 27 May 2006 earthquake and eruption of Mount Merapi in Yogyakarta district, Java island with 6.3 Magnitude. The $28^{\text {th }}$ September 2018, earthquake and tsunami occured in Donggala and Palu, Sulawesi Island with 7.3 Magnitude. Several buildings and infrastructures collapsed that was affected by earthquake tremor. The estimated material losses in government and society are more than billion rupiahs. It is very important for the government to give socialization about implementation of the early warning system and explanation the regions that have active fault. The object location of this research is in Bandar Lampung City, Lampung Province, Indonesia. Lampung is located at the southermost of Sumatera island that has two active fault, they are Tarahan fault and Semangko fault. Suharno \& Mulyatno (2007) based on the data of highest earthquake spectral Lampung Province in 1990 to 2004 state that Liwa district has earthquake spectral more than $2400 \mu \mathrm{m} \mathrm{s}^{-2}$ and then Bandar Lampung City is one of lower earthquake spectral approximately 400 to $500 \mu \mathrm{m} \mathrm{s}^{-2}$. Therefore, it needs an action to prevent collapsed building that affected by earthquake load and movement active fault that may occur.

To prevent collapsed building due to earthquake load, as an engineer, one should design the building performance based on strong column weak beam. Liu et.al (2012) stated according to demand of seismic 
concept design of buildings, frame structures should have multiple lines of seismic resistance, one of which is the strong column-weak beam. But, another method to give stiffening system namely, using steel bracing frame that can reduce the story drift which is affected by earthquake load. The purpose of this study is to analyze performance of story drift in 2 (two) buildings structures that every models has applied stiffening lateral, namely: $x$-braced frame, and the two story $x$-braced frame. This research using spectral design of Bandar Lampung city, soft soil category, and building design in concentric braced frame of steel material. Earthquake spectral design based on the earthquake map and rule of policy in SNI 03-1726-2012 guidelines about earthquake resistance implementation for building and nonbuilding. This research will compare horizontal deflection (story drift) due to the earthquake load in accordance to response spectra procedure anlysis. This study expected as a recommendation type of brace frame selection that is more optimal in carrying an earthquake loads, especially high-rise buildings steel structure where will be utilized in Bandar Lampung City.

\section{Braced frame}

The structure of a high-rise building must be planned to be able bearing the burdens it receives. These expenses include: dead load, live load, wind load and especially earthquake load. One of effort that to improve the performance of building structures in resisting earthquake forces is to provide additional structural stiffness that can be applied using a lateral stiffening system. Brace frame is one of method to give lateral stiffening system in building structure, especially in steel building structure. There are two main varieties of braced frames namely, concentric brace frame and eccentric brace frame. Concentric bracing consists of diagonal braces located in the plane of the frame as shown in Figure 1. Both ends of the brace join at the end points of other framing members to form a truss, creating a stiff frame. Whereas for eccentric bracing consists of diagonal braces located in the plane of the frame where one or both ends of the brace do not join at the end points of other framing members as shown in Figure 2.
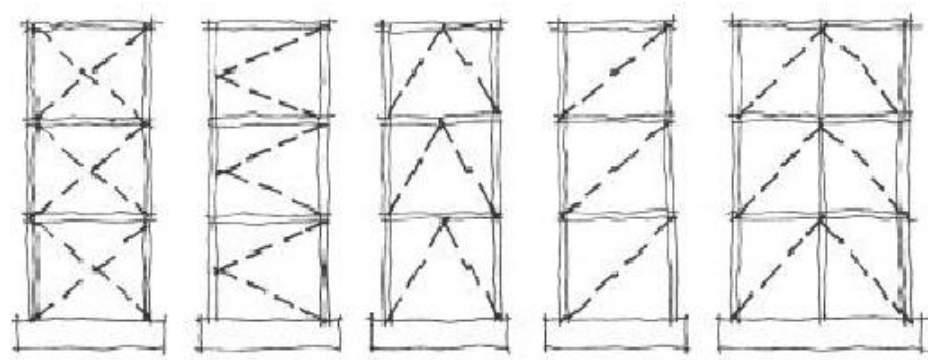

Figure 1. Common types of concentric braced framing

Source: www.seismicresilience.org.nz
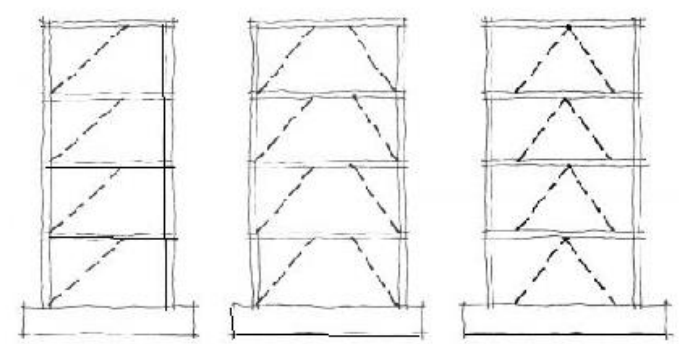

Figure 2. Common types of eccentric braced framing Source: $\underline{\text { www.seismicresilience.org.nz }}$

There are several steel brace configuration of concentrically brace frame such as, diagonal bracing, inverted v-bracing, v-bracing, two story $\mathrm{x}$-bracing and $\mathrm{x}$-bracing (Seker, 2015). Bracing frame will act 
stiffener in structure system. In this study, steel brace frame that used in modeling is concetric braced framing, they are two story $\mathrm{x}$-bracing and $\mathrm{x}$-bracing models, as shown in figure 3 .

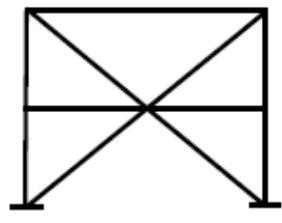

a. Two-story $\mathrm{X}$ bracing

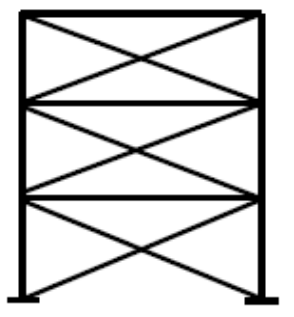

b. X bracing

Figure 3. Concentric brace frame configuration

\section{Methods}

\subsection{Design response spectra and load combination}

Based on design response spectra data from the Research and Development Agency of the Ministry of Public Works and Public Housing in 2017, Bandar Lampung City, the bedrock acceleration value 1 second (S1) is in the range of 0.3-0.4 $\mathrm{g}$ and bedrock acceleration values 0.2 seconds ( $\mathrm{Ss}$ ) is in the range of $0.7-0.8 \mathrm{~g}$.

The seismic load was designed using dynamic response spectrum method based on SNI 03-1726-2012. The response spectra parameter was taken from the website of Ministry of Public Works of Republic Indonesia by entering name of location and category of site soil on the website http://puskim.pu.go.id/Aplikasi/desain_spektra_indonesia_2011/. In this study, location of study is in City of Bandar Lampung, with result of soil investigation is in E category soft soil. The website of application design spectra gives the output data of parameter response spectrum as shown at Table 1.

Table 1. Spectral response graphic design parameter

\begin{tabular}{cl}
\hline Spectral Response Parameter & Value \\
\hline $\mathrm{S}_{\mathrm{s}}$ & $0.739 \mathrm{~g}$ \\
$\mathrm{~S}_{1}$ & $0.318 \mathrm{~g}$ \\
$\mathrm{~S}_{\mathrm{DS}}$ & 0.602 second \\
$\mathrm{S}_{\mathrm{D} 1}$ & 0.578 second \\
$\mathrm{Ts}$ & 0.192 second \\
$\mathrm{To}$ & 0.960 second \\
\hline
\end{tabular}

where;

$\mathrm{S}_{\mathrm{DS}} \quad=$ spectral response acceleration parameter on a short period, $5 \%$ damping

$\mathrm{S}_{\mathrm{D} 1} \quad=$ spectral response acceleration parameter design on a 1 second period

To and $\mathrm{Ts} \quad=$ fundamental structural vibration period 


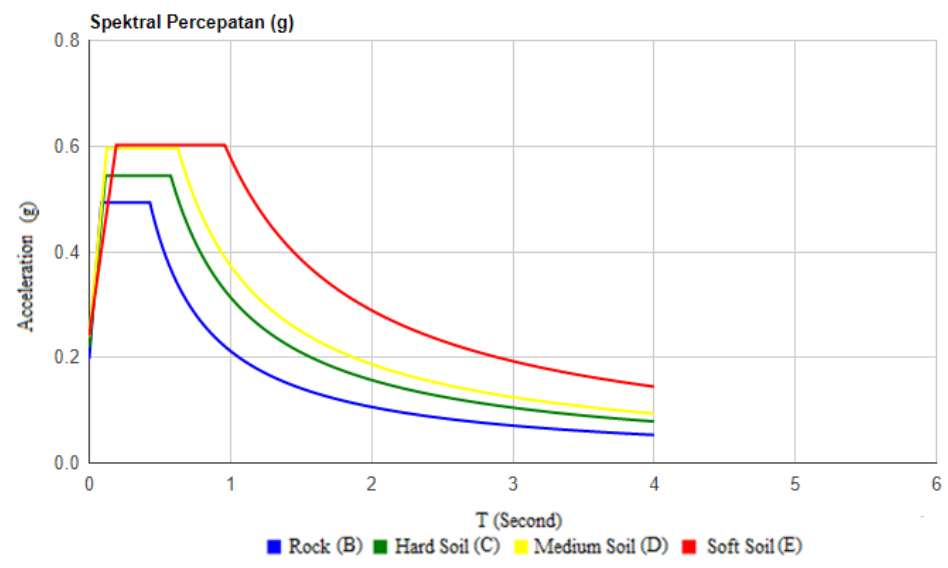

Figure 1. Graphic of design response spectrum on the location of research object.

Source : http://puskim.pu.go.id/Aplikasi/desain_spektra_indonesia_2011

Based on SNI 03-1726-2012 section 4.1.2 about concerning the risk category of building structure, the research object includes as a hotel, and included in the risk category II, then the occupancy importance factor $\left(I_{e}\right)$ is 1.00. Based on SNI 03-1726-2012 section 6.5 state that concerning the determination of Seismic Design Category (KDS), for SDS values of $0.602 \mathrm{~g}$, SD1 values of $0.578 \mathrm{~g}$ and risk category II (hotel/ apartment buildings), obtained by type the Seismic Design Category (KDS) is D. In section 7.4.2 state that the combination of loading entered into the loading analysis must take into account the SDS and SD1 value factors. The load combination inserted in modeling. The following results of the analysis of the combination of loading for nominal dead load, nominal life load and nominal earthquake load which are included in ETABS modeling for SDS value of $0.602 \mathrm{~g}$ and SD1 value of $0.578 \mathrm{~g}$.

- $1,4 \mathrm{DL}$

- $1,2 \mathrm{DL}+1,6 \mathrm{LL}$

- $1,12 \mathrm{DL}+1 \mathrm{LL}+0,3 \mathrm{Qx}-\mathrm{Qy}$

- 1,28DL + 1LL - 0,3 Qx + Qy

- 1,36DL + 1LL + 0,3 Qx + Qy

- $1,04 \mathrm{DL}+1 \mathrm{LL}-0,3 \mathrm{Qx}-\mathrm{Qy}$

- $1,28 \mathrm{DL}+1 \mathrm{LL}+\mathrm{Qx}-0,3 \mathrm{Qy}$

- $1,12 \mathrm{DL}+1 \mathrm{LL}-\mathrm{Qx}+0,3 \mathrm{Qy}$

- 1,36DL + 1LL + Qx + 0,3 Qy

- $1,04 \mathrm{DL}+1 \mathrm{LL}-\mathrm{Qx}-0,3 \mathrm{Qy}$

where; DL = Dead Load, LL = Live Load and Qx,y = Seismic Load $/$ Response Spectra,

The dead load and live load is computed in accordance to PPPURG (Pedoman Perencanaan Pembebanan Untuk Rumah dan Gedung) 1989 guidelines and SNI 03-1727-2013 guidelines about minimum load for building plans and other structures.

\subsection{Modeling building properties}

Building modeling is designed using steel material. The frame system in the portal frame building structure for beams and columns elements were modeled using the ETABS software program in three dimensions. The building model utilize the principle of earthquake force restraint system which is Intermediate Moment Resisting Steel Frame (IMRSF). The response modification coefficient value (R) is 3.25 and in accordance to section 7.2.2 Table 9, point B.3 (concentrically steel braced frame) on SNI 02-1727-2012. The data building properties that is inputed according to document of engineering consultant, as shown in Table 2. 
Table 2. Building properties

\begin{tabular}{ll}
\hline \multicolumn{1}{c}{ Building description } & \multicolumn{1}{c}{ Information } \\
\hline Building function & Hotel \\
Highest elevation and lowest elevation & $+39.40 \mathrm{~m} \mathrm{dan}-3.00 \mathrm{~m}$ \\
Total of stories and basement & 11 stories dan 1 basement \\
Basement story height & $3.00 \mathrm{~m}$ \\
Typical story height (story base and story 1) & $3.80 \mathrm{~m}$ \\
Typical story height (story 2 to story 10) & $3.20 \mathrm{~m}$ \\
Quality of steel material profile & $\mathrm{BJ}-37 \mathrm{Fu}=370 \mathrm{MPa}$ \\
& $\mathrm{Fy}=240 \mathrm{Mpa}$ \\
Quality of concrete compressive strength (f'c) for slab & $25 \mathrm{MPa}$ \\
Total building area & $599.48 \mathrm{~m}^{2}$ \\
Vertical connector & Lifts dan stairs \\
Main column using profile wide flange shape & $900 \times 300 \times 16 \times 38 \mathrm{~mm}$ \\
Main beam using profile wide flange shape & $588 \times 300 \times 13 \times 20 \mathrm{~mm}$ \\
Brace frame using profile channel & $300 \times 90 \times 12 \times 16 \mathrm{~mm}$ \\
\hline
\end{tabular}

In this study, building models that was planned as typical floor, then the building models was made into two types of building models. Firstly building model using two story x-braced frame, and secondly building model using $\mathrm{x}$-braced frame. Typical building plan was modified with the addition of type steel $\mathrm{x}$-bracing and type two story $\mathrm{x}$-bracing where is placed on the right and left edges of the building portal, as seen in Figure 4-5.

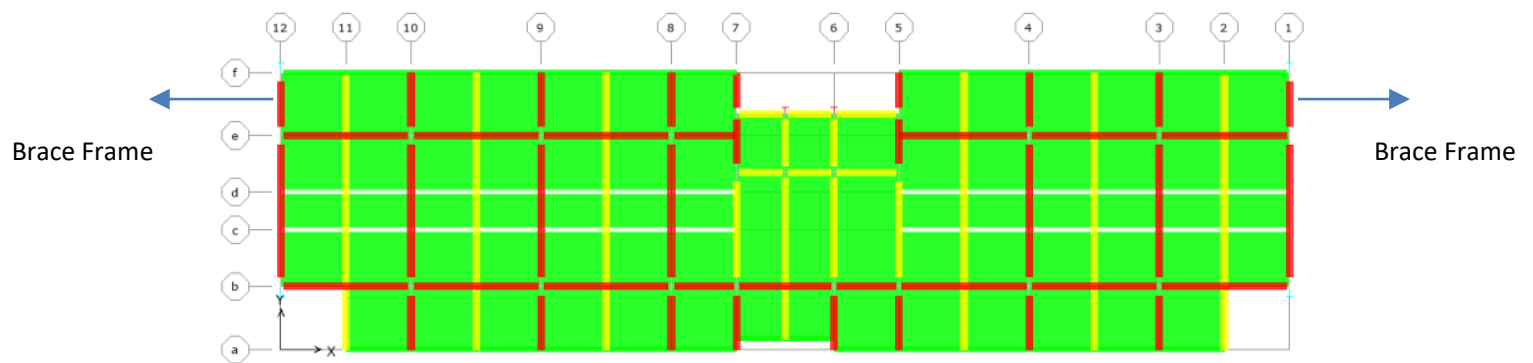

Figure 4. Typical floor plan in modeling ETABS program with location brace frame

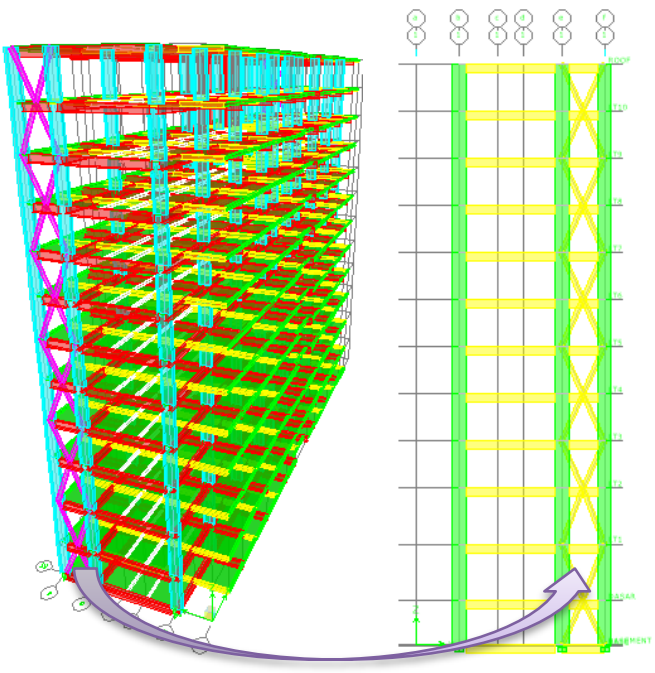

1) Modeling 1: Two story $x$-bracing frame

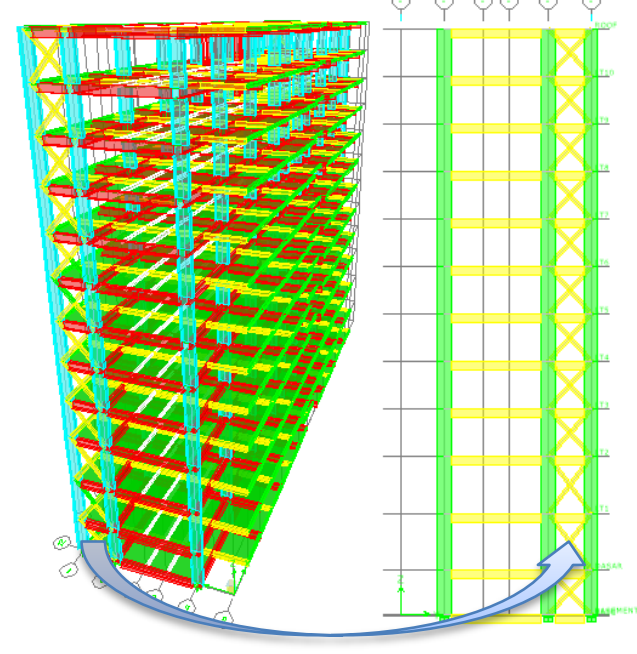

2) Modeling $2: x$-bracing frame

Figure 5. Types of steel brace frame in buiding models 


\subsection{Story drift analysis}

The ultimate limit performance of the building can be obtained through the calculation of story drift analysis. "Story drift" is the maximum lateral displacement within a story (i.e., the displacement of one floor relative to the floor below caused by the effects of seismic loads) (FEMA 450, 2003). Ultimate limit performance is purposed to prevent the collapse of building structures that can cause fatality of death and collision between buildings.

The results of structural analysis will produce internal forces namely, moment force, shear force, torque force and axial force. The ETABS program can show output data in the form of seismic shear force values for each level and displacement values. The displacement value is called as the elastic displacement value on the level $\mathrm{x}(\delta \mathrm{xe})$. The value of the deflection between the level is enlarged $(\Delta \mathrm{x}, \mathrm{y})$ by multiplying result from the value of the deflection amplification factor $(\mathrm{Cd})$ and the difference between the elastic displacement on the upper and lower levels, then the results are divided by an occupancy importance factor factor (Ie). According to SNI 03-1726-2012 section 7.8.6 and FEMA 450 part 1 : provision section 5.2.6, the design story drift shall be computed as the difference of the deflections at the center of mass at the top and bottom of the story under consideration. The deflection of level $x, \Delta_{x, y}$, shall be determined in accordance with following the equation (Eq.1 and Eq.2).

$$
\begin{aligned}
& \Delta x, y=\frac{C_{d} \cdot \delta_{x e}}{I e} \\
& \Delta x, y=\frac{C_{d} \cdot\left(\delta_{e 2}-\delta_{e 1}\right)}{I e}
\end{aligned}
$$

where;

$\mathrm{C}_{\mathrm{d}} \quad=$ deflection amplification factor in accordance to SNI 03-1726-2012 section 7.2.2

$\mathrm{I}_{\mathrm{e}} \quad=$ the occupancy importance factor determined in accordance to SNI 03-1726-2012 section 4.1.2

$\delta_{\mathrm{xe}} \quad=$ the deflections determined by an elastic analysis

$\Delta \mathrm{x}, \mathrm{y} \quad=$ the value of the deflection between the story that was enlarge or story drift in level $\mathrm{x}$

Story drift is limited using drift permit equation in accordance to SNI 03-1726-2013 section 7.12.1 Table 16 states that deflection limit or story $\operatorname{drift}(\Delta \mathrm{a})$ should be calculated by equation (Eq.3). If the story drift bigger than drift permit, then story drift is stated an unsafe condition.

$$
\Delta \mathrm{a}_{\mathrm{x}, \mathrm{y}}=0.002 \mathrm{~h}_{\mathrm{sx}}
$$

where;

$\mathrm{h}_{\mathrm{sx}} \quad=$ height of story

\section{Result and discussion}

The models was analyzed using ETABS and the output data such displacement, the building mass, the internal forces, story shear, and so on provided ETABS. Before the program was run, it needs to make sure that the mass participation ratio might be over $90 \%$ on the orthogonal direction of the model.

The analysis must follow the standard of SNI 03-1726-2012 detailed on section 7.9.4.1. There explained if the value of seismic base shear force of the response spectrum analysis $(\mathrm{Vt})$ is $85 \%$ smaller than the seismic base shear force lateral in equivalent static analysis $\left(\mathrm{V}_{1}\right)$, then the story shear in $\mathrm{x}$ and $\mathrm{y}$-direction $(\mathrm{Vx}, \mathrm{y})$ value must be multiplied by the force scale factor of $\left(0.85 \mathrm{~V}_{1}\right) / \mathrm{Vt}$. Meanwhile in section 7.3.4.2, explain that the loading of seismic story shear force of the response spectrum $(\mathrm{Vx}, \mathrm{y})$ in each levels must considered to calculate the value of the redundancy factor $(\rho)$. If the Vt value at each level does not meet $35 \%$ of $\mathrm{Vt}$ in $\mathrm{x}$ and $\mathrm{y}$ direction, then the value of $\mathrm{Vt}$ must be multiplied by the redundancy factor $(\rho)$ of 1.30. If each floor meets $35 \%$ of $\mathrm{Vt}$, then the value of $\rho$ is 1.00 . In ETABS program, the value of redundancy factor can be entered in the ETABS menu, with select Define >Responses Spectrum Cases> 
on the scale factor $\left(\left(\mathrm{I}_{\mathrm{e}} / \mathrm{R}\right)\right.$ multiplied by the gravitation), and then multiplied again by the redundancy factor values for the directions of $\mathrm{U} 1$ and $\mathrm{U} 2$.

Story shear $\left(\mathrm{V}_{\mathrm{x}, \mathrm{y}}\right)$ is the value of shear force from the dynamic loading in every level of the building that was calculated in accordance with the response spectra analysis. The story shear had been multiplied by the redundant factor $(\rho)$ of 1.30 . The story shear presented on Table 3.

Table 3. Story shear force of $\mathrm{x}$ and $\mathrm{y}$-direction in 2 (two) types braced frame models

\begin{tabular}{crrrrrr}
\hline $\begin{array}{c}\text { Story } \\
\text { Level }\end{array}$ & $\begin{array}{c}\text { Story } \\
\text { Height }(\mathrm{m})\end{array}$ & \multicolumn{2}{c}{ Building } & \multicolumn{2}{c}{ x-braced frame } & \multicolumn{2}{c}{ Two story x-braced frame } \\
Elevation $(\mathrm{m})$ & $\mathrm{V}_{\mathrm{x}}(\mathrm{kN})$ & $\mathrm{V}_{\mathrm{y}}(\mathrm{kN})$ & \multicolumn{1}{c}{$\mathrm{V}_{\mathrm{x}}(\mathrm{kN})$} & \multicolumn{1}{c}{$\mathrm{V}_{\mathrm{y}}(\mathrm{kN})$} \\
\hline Roof & 0.00 & 39.40 & 700.75 & 1282.18 & 675.88 & 1197.74 \\
10 & 3.20 & 36.20 & 1233.70 & 2250.04 & 1193.41 & 2124.04 \\
9 & 3.20 & 33.00 & 1635.76 & 2978.57 & 1588.42 & 2841.19 \\
8 & 3.20 & 29.80 & 1961.67 & 3544.74 & 1911.04 & 3404.67 \\
7 & 3.20 & 26.60 & 2241.60 & 4002.73 & 2186.13 & 3857.04 \\
6 & 3.20 & 23.40 & 2487.59 & 4401.40 & 2426.67 & 4250.03 \\
5 & 3.20 & 20.20 & 2711.62 & 4781.31 & 2645.49 & 4620.76 \\
4 & 3.20 & 17.00 & 2920.23 & 5161.90 & 2850.13 & 4988.00 \\
3 & 3.20 & 13.80 & 3121.22 & 5537.32 & 3048.34 & 5349.15 \\
2 & 3.20 & 10.60 & 3323.03 & 5885.32 & 3247.66 & 5683.95 \\
1 & 3.80 & 6.80 & 3503.98 & 6150.20 & 3413.55 & 5921.28 \\
Ground & 3.80 & 3.00 & 3619.98 & 6258.04 & 3519.11 & 6014.94 \\
Basement & 3.00 & 0.00 & 3620.42 & 6259.40 & 3519.48 & 6015.82 \\
\hline
\end{tabular}

Table 3 shown that the result of structure analysis from ETABS program was descripted the differentiation value in the story shear in 2 (two) types of the building models. The highest value of the base shear $(\mathrm{Vt})$ braced frame model is $\mathrm{x}$-braced frame is about $6259.40 \mathrm{kN}$ in y-direction. Whereas the value of base shear $(\mathrm{Vt})$ in two story $\mathrm{x}$-braced frame is about $6015.82 \mathrm{kN}$ in y-direction.

This study shown that the story shear in $\mathrm{x}$-braced frame frame is bigger than two story $\mathrm{x}$ braced frame. The shear force that was done by ETABS would be resulted the horizontal deflection along $\mathrm{x}$ and $\mathrm{y}$ direction. The ultimate limit performance in the buildings model is the maximum value of story drift.

The story drift calculatd from the result of the multiplication between the horizontal deflection and the story levels. The value of deflection amplification factor $(\mathrm{Cd})$, then divided by the occupancy of importance factor $\left(\mathrm{I}_{\mathrm{e}}\right)$. In this model, the value of $\mathrm{Cd}$ is 3.25 , because of the building was designed as the Intermediate Moment Resisting Steel Frame (IMRSF) using concetrically steel braced frame, according to SNI 02-1727- 2012 in the table 9 point B.3.

Based on SNI 03-1726-2012 section 4.1.2 it mention that the risk category of the building structure, the building categorized as a hotel building so that it is included in the risk category II, then the occupancy importance factor $\left(\mathrm{I}_{\mathrm{e}}\right)$ is 1.00 . Story drift is limited using drift permit equation in accordance with SNI 03-1726-2013 section 7.12.1. The evaluation of story drift anaysis shown on Table 4. 
Table 4. Story drift from ultimate limit performance of $\mathrm{x}$ and $\mathrm{y}$-direction in two story $\mathrm{x}$-braced frame

\begin{tabular}{|c|c|c|c|c|c|c|}
\hline \multirow{2}{*}{ Story } & $\begin{array}{c}\text { Commulative } \\
\text { of Height }\end{array}$ & $\begin{array}{c}\text { Drift Permit } \\
\left(\Delta \mathbf{a}_{\mathbf{x}, \mathbf{y}}\right)\end{array}$ & $\begin{array}{c}\text { Story Drift-x } \\
(\Delta \mathbf{x})\end{array}$ & Evaluate & $\begin{array}{c}\text { Story Drift-y } \\
(\Delta y)\end{array}$ & Evaluate \\
\hline & $(\mathbf{m m})$ & $(\mathbf{m m})$ & $(\mathbf{m m})$ & $\Delta \mathbf{x}<\Delta \mathbf{a}_{\mathbf{x}, \mathbf{y}}$ & $(\mathbf{m m})$ & $\Delta \mathbf{y}<\Delta \mathbf{a}_{\mathbf{x}, \mathbf{y}}$ \\
\hline Roof & 39400 & 64.00 & 11.37 & Yes & 22.42 & Yes \\
\hline 10 & 36200 & 64.00 & 19.64 & Yes & 25.53 & Yes \\
\hline 9 & 33000 & 64.00 & 27.33 & Yes & 28.38 & Yes \\
\hline 8 & 29800 & 64.00 & 34.28 & Yes & 31.19 & Yes \\
\hline 7 & 26600 & 64.00 & 40.63 & Yes & 33.03 & Yes \\
\hline 6 & 23400 & 64.00 & 46.51 & Yes & 34.66 & Yes \\
\hline 5 & 20200 & 64.00 & 52.03 & Yes & 35.73 & Yes \\
\hline 4 & 17000 & 64.00 & 57.24 & Yes & 36.19 & Yes \\
\hline 3 & 13800 & 64.00 & 63.36 & Yes & 36.40 & Yes \\
\hline 2 & 10600 & 76.00 & 105.78 & No & 42.64 & Yes \\
\hline 1 & 6800 & 76.00 & 110.99 & No & 35.87 & Yes \\
\hline Ground & 3000 & 60.00 & 55.04 & Yes & 13.11 & Yes \\
\hline Basement & 0 & 0.00 & 0.10 & - & 0.06 & - \\
\hline
\end{tabular}

Table 5. Story drift from ultimate limit performance of $\mathrm{x}$ and $\mathrm{y}$-direction in $\mathrm{x}$-braced frame

\begin{tabular}{|c|c|c|c|c|c|c|}
\hline \multirow[t]{2}{*}{ Story } & $\begin{array}{c}\text { Commulative } \\
\text { of Height }\end{array}$ & $\begin{array}{c}\text { Drift Permit } \\
(\Delta \mathbf{a x}, \mathbf{y})\end{array}$ & $\begin{array}{l}\text { Story Drift-x } \\
(\Delta \mathbf{x})\end{array}$ & Evaluate & $\begin{array}{c}\text { Story Drift-y } \\
(\Delta y)\end{array}$ & Evaluate \\
\hline & $(\mathbf{m m})$ & $(\mathbf{m m})$ & $(\mathbf{m m})$ & $\Delta \mathbf{x}<\Delta \mathbf{a}_{\mathbf{x}, \mathbf{y}}$ & $(\mathbf{m m})$ & $\Delta \mathbf{y}<\Delta \mathbf{a}_{\mathbf{x}, \mathbf{y}}$ \\
\hline Roof & 39400 & 64.00 & 11.66 & Yes & 24.12 & Yes \\
\hline 10 & 36200 & 64.00 & 20.11 & Yes & 26.95 & Yes \\
\hline 9 & 33000 & 64.00 & 27.94 & Yes & 29.63 & Yes \\
\hline 8 & 29800 & 64.00 & 32.50 & Yes & 32.05 & Yes \\
\hline 7 & 26600 & 64.00 & 44.02 & Yes & 34.09 & Yes \\
\hline 6 & 23400 & 64.00 & 47.50 & Yes & 35.62 & Yes \\
\hline 5 & 20200 & 64.00 & 53.13 & Yes & 36.55 & Yes \\
\hline 4 & 17000 & 64.00 & 58.43 & Yes & 36.73 & Yes \\
\hline 3 & 13800 & 64.00 & 64.67 & No & 36.13 & Yes \\
\hline 2 & 10600 & 76.00 & 107.92 & No & 41.13 & Yes \\
\hline 1 & 6800 & 76.00 & 113.64 & No & 33.06 & Yes \\
\hline Ground & 3000 & 60.00 & 56.51 & Yes & 12.53 & Yes \\
\hline Basement & 0 & 0.00 & 0.10 & - & 0.07 & - \\
\hline
\end{tabular}




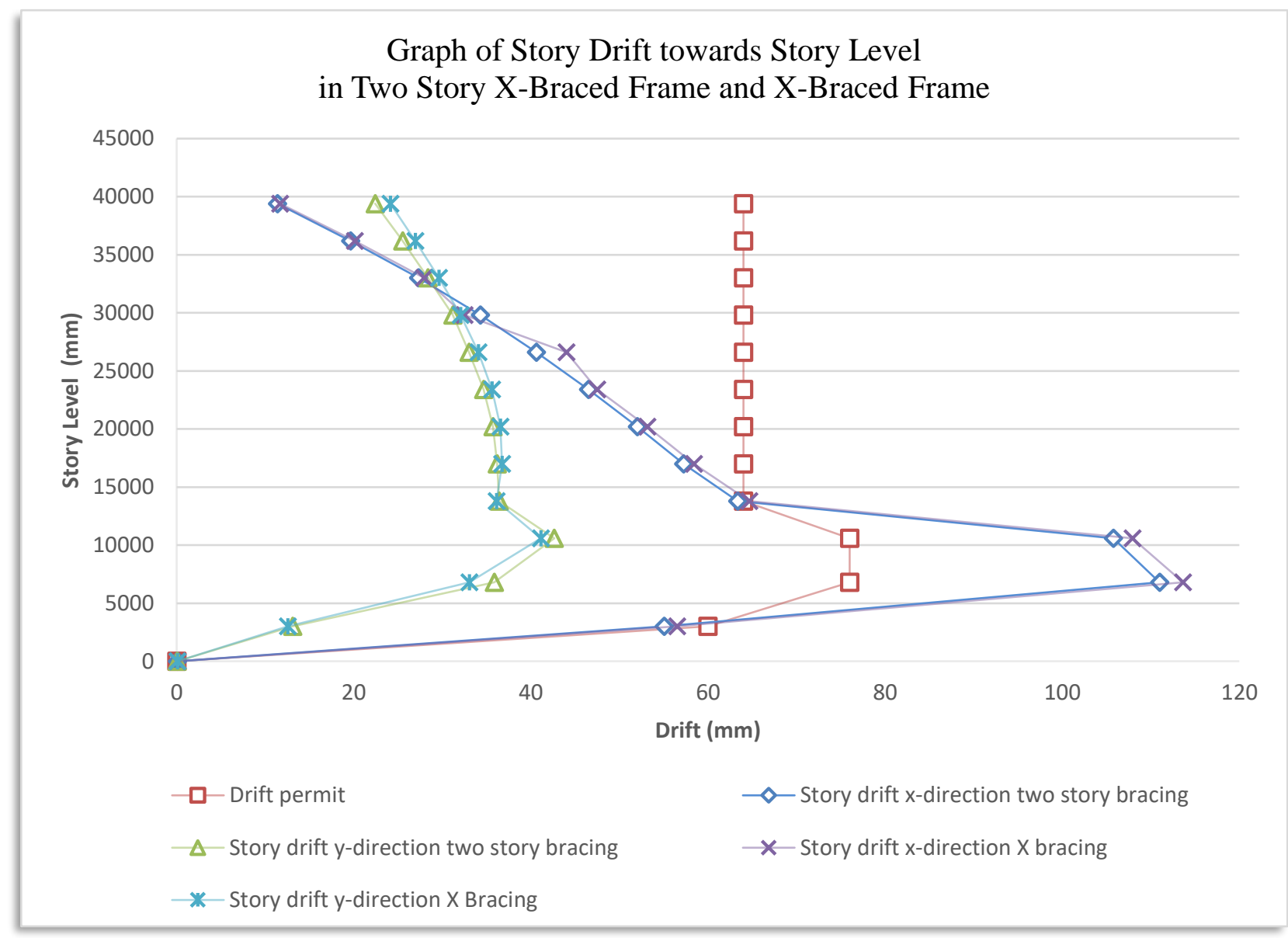

Figure 6. Graph Story drift towards story level

Table 4 shown that the maximum value of the story drift with two $\mathrm{x}$-braced frame as amount $110.99 \mathrm{~mm}$ in $\mathrm{x}, \mathrm{y}$ direction. And the table 5 shown the maximum value if the story drift with $\mathrm{x}$-braced frame as amount $113.64 \mathrm{~mm}$ in $\mathrm{x}, \mathrm{y}$ direction. The difference value of both model is $2.65 \mathrm{~mm}$. However, these values are not significantly different. But, this analysis indicate that the building with two story $\mathrm{x}$-braced frame is considerable than the $\mathrm{x}$-braced frames, hence type of two story $\mathrm{x}$-braced frame model provide the smaller value of the story drift along $\mathrm{x}, \mathrm{y}$-direction.

Figure 6 explained that the stiffness of the column is greatly affected by the heigh of the story level, thus if the shear force happen, then the story drift will be increased. This occurs at the elevations of story 1 and 2 in both models.

Applying the braced frame designed in accordance with SNI 03-1726-2012 are expected to provide the limited inelastic deformation capacity in their members and connections. Mechnism of the elacticity in this building is expected to describe the capability of structure element on column, beam, and braced frame while excepted ultimate loads. Therefore elastic condition is limited by placiticity or inelastic condition.

\section{Conclusion}

A Building should capable to resist the load especially under the earthquakes loading. Thus, it expected that the building should have the proper building stiffness to resist the elastic condition. Take the 
contribution of the column height, inertial moment, and elasticity modulus as the parameter of the building stiffness.

Story drift in building can be calculted by ETABS program with response spectra analysis. In this study, it was found that the model with two story x-braced frame is more effective than the type of x-braced frame. Provision of appropriate structural stiffness can improve the ultimate limit performance in the buildings, thus reducing horizontal deflection between two floors (story drift) in $\mathrm{x}$-and $\mathrm{y}$ directions.

\section{References}

[1] FEMA 4502003 Handbook on The NEHRP Recommended Provisions for Seismic Regulations for New Buildings and other Structures, Part 1 Provision (Washington D.C: Building Seismic Safety Council for the Federal Emergency Management Agency) p 91

[2] Seker P T 2015 Effect of beam strenght on seismic performance of two-stroy X-braced frames (Ames : Theses and Dissertation in Iowa State University) $\mathrm{p} 1$

[3] Liu Y, Yuanxin L, Nina Z and Jingbo L Analysis of Strong Column and Weak Beam Behaviour of Steel-Concrete Mixed Frames 2012 Portugal. Proceeding of The Fifthteenth World Conference on Earthquake Egineering

[4] PPPURG-1989 1989 Pedoman Perencanaan Pembebanan untuk Rumah dan Gedung (Jakarta: Departemen Pekerjaan Umum)

[5] SNI 03-2847-2013 2013 Persyaratan Beton Struktural untuk Bangunan Gedung, Badan Standardisasi Nasional Indonesia (Jakarta: Badan Stadardisasi Nasional)

[6] SNI 03-1726-2012 2012 Tata Cara Ketahanan Perencanaan Ketahanan Gempa untuk Struktur Bangunan Gedung dan Non-Gedung (Jakarta: Badan Stadardisasi Nasional)

[7] SNI 03-1727-2013 2013 Beban minimum untuk perancangan bangunan gedung dan struktur lain. (Jakarta: Badan Stadardisasi Nasional)

[8] www.seismicresilience.org.nz Braced frame, downloaded in 01/09/2018 on website adrress : http://www.seismicresilience.org.nz/topics/superstructure/seismic-design-concepts/bracedframes/

[9] Suharno and Baguss S M Distribusi Peluang Tingkat Resiko Gempa Wilayah Provinsi Lampung berdasarkan Data Gempa 1990 - 2004 2007. J. Sains MIPA. (13:3) pp 221-227

\section{Acknowledgments}

This research is funded by LP3 Institut Teknologi Sumatera, Lampung Indonesia. These financial supports are gratefully acknowledgments, so that authors can follow the event International Conference on Science Infrastructure Technology and Regional Development (ICoSITeR) on October 2018, in Lampung Indonesia. 